"The reflective assessment on the acquisition of life value in customer education as a character building dimension"

\begin{tabular}{|c|c|}
\hline AUTHORS & Sri Wening \\
\hline ARTICLE INFO & $\begin{array}{l}\text { Sri Wening (2019). The reflective assessment on the acquisition of life value in } \\
\text { customer education as a character building dimension. Problems and } \\
\text { Perspectives in Management, 17(1), 42-55. doi:10.21511/ppm.17(1).2019.05 }\end{array}$ \\
\hline DOI & http://dx.doi.org/10.21511/ppm.17(1).2019.05 \\
\hline RELEASED ON & Friday, 08 February 2019 \\
\hline RECEIVED ON & Monday, 05 November 2018 \\
\hline \multirow[t]{2}{*}{ ACCEPTED ON } & Wednesday, 23 January 2019 \\
\hline & $((c)) E Y$ \\
\hline LICENSE & $\begin{array}{l}\text { This work is licensed under a Creative Commons Attribution } 4.0 \text { International } \\
\text { License }\end{array}$ \\
\hline JOURNAL & "Problems and Perspectives in Management" \\
\hline ISSN PRINT & $1727-7051$ \\
\hline ISSN ONLINE & $1810-5467$ \\
\hline PUBLISHER & LLC "Consulting Publishing Company "Business Perspectives" \\
\hline FOUNDER & LLC "Consulting Publishing Company "Business Perspectives" \\
\hline
\end{tabular}

NUMBER OF REFERENCES

40

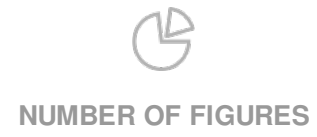

0
NUMBER OF TABLES

4

(C) The author(s) 2022. This publication is an open access article. 


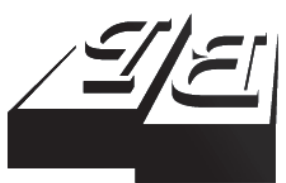

BUSINESS PERSPECTIVES

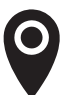

LLC "CPC "Business Perspectives" Hryhorii Skovoroda lane, 10, Sumy, 40022, Ukraine

www.businessperspectives.org

Received on: $5^{\text {th }}$ of November, 2018 Accepted on: $23^{\text {rd }}$ of January, 2019

(C) Sri Wening, 2019

Sri Wening, Dr., Faculty of Engineering, Yogyakarta State University, Indonesia.

\section{THE REFLECTIVE ASSESSMENT ON THE ACQUISITION OF LIFE VALUE IN CUSTOMER EDUCATION AS A CHARACTER- BUILDING DIMENSION}

\begin{abstract}
Formal education plays a big role in the construction and development of students' competence and skill. A survey on the fashion engineering education in Indonesia found that most students had not appropriately applied the competence and skill they learned. Many of them did not say anything despite experiencing loss, were reluctant to ask for exchange or compensation, littered the product's waste, and had no interest in using do-it-yourself (DIY) skills to make their own products. Therefore, this study is aimed at depicting the importance of learning the Consumer Education materials, the application of living values in the Consumer Education materials, and the effectiveness of consumer living values on students' character-building. In this survey-based study, the ex post facto approach was used in order to evaluate the results of Consumer Education learning through reflective assessment sheet. The research population was 123 students of Fashion Engineering Education Study Program in higher education in stitutions in Yogyakarta Province who had passed the Consumer Education course in the odd semester in Indonesia in 2017. The sample was established through the stratified proportional random sampling technique, while the descriptive statistical analysis was applied to the findings of reflective assessment. The results show the students agree that learning Consumer Education course is imperative for day-to-day life and the Consumer Education materials are found to be effective in consumers' characterbuilding. This study has not internalized of the values through advice, example, discussion, role playing, and participation in the activities of consumption events around daily life. Further studies are needed for developing a relevant curriculum, training in designing content, strategies, instruments, and evaluation of learning.
\end{abstract}

\section{Keywords}

\section{JEL Classification}

\section{Consumer Education}

A23, D12

\section{INTRODUCTION}

In the practice, based on the experience that has been found from the survey and the observation over the Fashion Engineering in Indonesia, most of the students have not appropriately applied the skills and the competencies that they have mastered. Most of the students in the survey and observation reported that they should be dealing with the following issues within the domain: 1) experience of being lost; 2) reluctance for proposing exchange or compensation; 3 ) waste products; and 4) zero interest in performing do-it-yourself (DIY) skills for crafting their own products. These issues ultimately demand a reflective assessment on the curriculum and materials in relation to the domain, specifically in relation to the curriculum and materials of the Customer Education Course. The reflective assessment itself should be directed to the life values that play a significant role for building the students' characters. 


\section{LITERATURE REVIEW}

Education is part of fundamental needs for any individual (Anonym, 2001; Elder, 2015). Through education, it is expected that the overall movement of an individual will be based on the divine and moral values. In relation to the statement, the development in the international world within the domain of economy, politics and even social culture demands improvement on human resources quality so that the human resources will be readier, be more responsive, and be stronger in dealing with the development. Therefore, the Department of National Education has been pursuing numerous efforts to improve the educational quality so that the human resources quality might be improved as well. The fundamental changes for the educational quality improvement might be pursued through curriculum improvement, learning quality improvement, and evaluation system change (Widodo, 2015).

Changes and developments on the life aspects should be responded by professional and well qualified performance in education. Therefore, effective curriculum development should be to meet the needs and current demands of the culture, the society, and the expectations of the population being served (Alsubaie, 2016). The curriculum that has been developed nowadays demands a learning process that encourages the students to be more active and creative. At the same time, the same learning process emphasizes more on the process. As a result, there should be an evaluation toward the achievement of the curriculum that has been implemented into the learning process.

In relation to such changes and developments, Customer Education Course is a course that belongs to the domain of social science and is related to customer behaviors. Fry, Ketteridge, and Marshall (2009) mention that normally students are encouraged (or required, if it is a mandatory scheme) to keep a record of their learning achieved, both on the course and through their personal experience of work, voluntary activities, or other life experiences. They are also encouraged to reflect on how their learning matches the demands that will be made on them in the future by employers. In the learning process, Customer Education might be benefitted for developing the students' characteristics in relation to their daily life. The learning materials of the course themselves contain actual problems and life values within the society that have been related to the consumption behaviors and customer society protection. Then, the values of customer society life in the curriculum of Customer Education are classified into three aspects, namely the aspect of knowledge and skills in personal finance management, the aspect of wise purchase decision making, and the aspect of society participation. Thereby, the values in the Customer Education Course are the ones that will be able to deliver the society to both the individual and the communal happiness and prosperity.

In order to be successfully implemented, the curriculum of the course should aim at goal achievement, as well as expectation fulfilment in the society. To come to this aim, an assessment should be involved. According to Trespeces (1993), assessment is a process of describing, searching for, and sharing information that has been highly imperative within the decision-making activities for determining an alternative decision. Based on the definition, the term assessment might be applied to any process of collecting reality through a systematic manner for examining the changes on the students' behavior and the extent to which these changes occur (Lile \& Bran, 2014). As a result, assessment nowadays does not belong to the cognitive domain only, but also to the affective and the psychomotor domain. When the statement is put into the context of Customer Education Course, the assessment in the course thus becomes not only dealing with the students' cognitive aspects, but also with the students' affective and psychomotor aspect. In other words, the Customer Education Course will be dealing not only with the knowledge regarding customers, but also with the relevance between the knowledge and the daily life context. Since it is deemed that situation is worth to investigate, in the present study, the students' view on the significance and the usefulness of Customer Education Course in their daily life will be presented.

The success of curriculum implementation should, in fact, aim at the goal achievement, as well as how it suits society expectation. In order to measure the success of the curriculum achievement, an assessment might be involved. Assessment is part 
of a process of achieving an objective. According to Trespeces (1993), assessment is the process of describing, searching, and sharing information, which is highly imperative to a decision-making process in determining an alternative decision. The term also applies to a process of collecting realities in a systematic manner to examine any change in students' behavior and to what extent it occurs (Bloom, 2001). As assessment allows students to evaluate a learning process (Lile \& Bran, 2014), and in this study, it presents the students' view on the significance of Consumer Education in daily life and how it can be used as a guide in spending money. Moreover, assessment no longer predominantly belongs to the cognitive domain, but affective and psychomotor ones as well (Calendra \& Tamarrow, 2015). Consumer Education assessment evaluates not only the students' cognitive competence, but also their buying behavior. This suggests that Consumer Education is not only limited to mere knowledge, but also is highly relevant in day-to-day life.

Specifically, as has been explained above, the success of curriculum implementation might be measured through assessment, particularly in relation to the students' learning outcomes in the form of their competences and skills. According to Mardapi (2004), assessment has several purposes as follows: 1) to examine students' competence/ skill level, 2) to examine students' development and growth, 3) to identify students' learning difficulties, 4) to identify learning outcomes, 5) to identify students' learning achievement, 6) to examine curriculum achievement, 7) to provide support for students, and 8) to motivate teachers to be better educators.

As one may have implied from previous explanations, assessment might also be understood as a process of revisiting previous activities that have been performed. Such process is aimed at revealing the strengths and the weaknesses of a program in order to improve it. The revisit itself might also be understood as reflection. Reflection bears similar meaning to standing in front of a big mirror in order to one's self. Such analogy explains why reflexivity is incorporated into the assessment process. Based on the process of assessment and reflection, a new teaching model is issued and the new teaching model is known as reflective teaching. Reflective teaching is a method that involves reflexivity for examining the effectiveness of learning activities that have been performed. The incorporation of reflexivity into teaching process is important in order to develop the students' quality. Pollard (2002) pointed out that reflective teaching bears several characteristics, namely: a) reflective teaching implies an active concern with aims and consequences, as well as means and technical efficiency; b) reflective teaching is applied in a cyclical or spiralling process, in which teachers monitor, evaluate and revise their own practice continuously; c) reflective teaching requires competence in methods of evidence-based classroom enquiry to support the progressive development of higher standards of teaching; and d) reflective teaching requires attitudes of open-mindedness, responsibility and wholeheartedness. These characters are closely related from one to another in progressively developing better teaching standards. Then, there are three important things that should be considered in designing the reflective teaching activities, namely: a) aim, b) evidence and reflection, and c) extension.

Bannister (1996) defined Costumer Education as the process of gaining the knowledge and skills to manage personal resources and to participate in social, political and economic decisions that affect individual well being and the public good. Consumer Education pays close attention to the awareness building and information transmission for changing individual's behaviors (McGregor, 2005). With regards to the present study, Customer Education is defined as the process of acquiring knowledge and skills for performing personal finance management, for taking actions on factors that influence customer decision-making aspects, and for being a good citizen.

The concept of Customer Education consists of five fundamental principles and the five principles are the customers' social responsibilities in performing their consumption for achieving customer protection. The five fundamental principles are: 1) critical awareness; 2) activity involvement; 3) social concern; 4) environmental concern; and 5) solidarity (Tantri, 1995, p. 24). Based on the five fundamental principles, it might be concluded that Customer Education has high level of impor- 
tance for increasing the students' awareness toward customer protection. In turn, the students of Customer Education Course will be able to motivate themselves for displaying the behaviours that are relevant to their life values and eventually for crystallizing these life values into the part of their characters.

According to Putrohari (2009), competence mastery refers to the mastery of knowledge, understanding, and skills through particular experiences. Knowledge itself is defined as a particular part of information. Then, understanding implies an ability to express the knowledge in numerous forms by seeing the links of particular knowledge to the other matters and to the existing problems. Last but not least, skills are defined as the knowledge in performing certain things. With regards to the Customer Education Course, the orientation of the competence mastery in the course is: 1) students' cognitive aspect attainment in the form of understanding and motivation; 2) self-reflection; and 3) students' capacity to actively contribute to the development of mindful consumers in the community (Stanszus et al., 2017). The mastery of these orientations will reflect how important the application of Customer Education into the daily life context is, since Customer Education shapes the students' characters for performing their consumption more wisely.

Looking at the content of the course, a competence-based assessment might be selected in order to assess the students' competence mastery. According to Yamin (2009), the purpose of competence-based assessment is to identify whether the basic competencies have been achieved or not so that the students' level of mastery might be determined. As a result, the critical thinking-based learning process that might be involved in the course will not only be related to the assessment of problem-solving product, but also to the assessment of problem-solving process, since the basic competence in the critical thinking-based learning process includes the ability to identify all kinds of problems that have been related to: 1) the customers' rights, responsibilities, and protection; 2) the understanding toward the background problems; 3) the problem formulation; 4) the discussions on the cause of the problems; 5) the ac- tions that should be taken; 6) the identification on the solutions for the problems; and 7) the provisions of conclusions and recommendations.

School is a secondary educational institution and a part of formal education that plays a significant role within the construction and the development of the students' knowledge, skills, attitudes, and values. The interaction between one student and another and also between the students and their environment involve numerous life values. These values are deliberately institutionalized through either formal regulations or written curricula. Furthermore, a school might also be considered as a place where personal values in the form of thoughts, comments, and actions meet one another. These values might emerge spontaneously through the unique personality that each student has in the school. With regards to the statement, David and Frank (1997) proposed that a school might be a strategic place for implementing the character education due to the fact that many children from various backgrounds are present in the school. Moreover, the children spend most of their times in the school and consequently the characters of these children will be largely influenced by the things that they have learned in the school.

\section{METHODS}

In conducting the study, the descriptive-evaluative approach was involved within the investigation on the attainment of Customer Education Course learning objectives. In addition, the reflective self-evaluation activities were also involved in order to uncover the perception of the students on the importance of learning the life values through the Customer Education Course, to identify the extent to which these values were manifested in their daily life, and to describe the effectiveness of the life values teaching for building the characters of wise customers. Then, the study consisted of several stages, namely: a) identifying the learning materials of Customer Education that were relevant to the students' needs; b) identifying the life values that were relevant to the competencies in the Customer Education; c) designing an instrument that measured how the life values had been practiced in the Customer Education as part of 
the dimensions within the characters building of the customers; d) gathering the necessary data by involving the respondents to complete the reflective practice questionnaire; and e) analyzing, interpreting, and synthesizing the data along with drawing conclusions.

Since the population in the study comprised of several homogenous groups, the study should involve a simple stratified proportional random sampling technique in determining the number of the respondents (Matthew et al., 2013). Due to the application of the simple stratified random sampling technique, there were 123 students from the Fashion Design and Hospitality Department of Yogyakarta State University who had been selected as the respondents for the study. The data from these respondents were gathered through the distribution of open-ended questionnaire that had been specifically design for functioning as a reflective assessment.

The field of social occupation and welfare was complex and full of challenges, since the decisions that should be made in the domain were by nature already difficult (Toros \& Medar, 2015). With regards to the statement, the prerequisite for better decision-making process was the presence of the systematic self-reflection practice (Amble, 2012). The systematic self-reflection practice enabled individuals to examine the decisions that they had made and the knowledge that they had involved within the practice (Heath, 1998). Self-reflection itself was significant part in students' training as the self-reflection enhanced the practice of their personal and professional development (Chaddock et al., 2014). Thus, self-reflection might improve the students' professional growth and competence (Eng \& Pai, 2014). In turn, the self-reflection might also improve the quality of the students' social occupation.

With regards to self-reflection, a reflective assessment sheet was assigned as part of research instrument for gathering the students' opinion on the life values that had been contained in the Customer Education Course. In addition, a reflection worksheet was also assigned in order to identify to which extent the students had implemented the contained life values in their daily life. In sum, the two instruments were designed in or- der to investigate to which extent the students had implemented the life values that had been taught in the Customer Education Course. The two instruments relied on 4-point Likert scale and the 4-point Likert scale would be elaborated as follows: a) $1=$ zero intention to practice the life values; b) $2=$ never practice the life values; c) $3=$ practice the life values; and d) $4=$ habituate the life values. The validity of the instrument was assessed by the experts' judgment within a focus group discussion and the data of the instrument were analyzed using the descriptive statistical analysis method.

Among the various approaches and techniques adopted in the strategic analysis and/or planning process, SWOT analysis was used here to explore the importance of learning the Consumer Education materials and the application of living values in the Consumer Education materials. In SWOT analysis, two critical environments (internal and external) are carefully analyzed and evaluated (Ololubel, Aiya, Uriah, \& Ololube, 2016).

Table 1. SWOT analysis on Consumer Education materials

\begin{tabular}{l:l}
\hline $\begin{array}{l}\text { Strength: Shaping the } \\
\text { character of students when } \\
\text { dealing with real consumption } \\
\text { activity. }\end{array}$ & $\begin{array}{l}\text { Weakness: Need long time } \\
\text { process to implementing life } \\
\text { value in consumption activity } \\
\text { for shaping consumption } \\
\text { for consumption. }\end{array}$ \\
$\begin{array}{l}\text { 1. Learning with case studies } \\
\text { of problems that occur in } \\
\text { real consumption activity. }\end{array}$ & $\begin{array}{l}\text { 1. Continous habituation. } \\
\text { formacter values are } \\
\text { formed after students } \\
\text { experience it. }\end{array}$ \\
$\begin{array}{l}\text { 2. Self reflection in responding } \\
\text { real case consumption. }\end{array}$ & \\
\hdashline $\begin{array}{l}\text { Opportunity: able to apply } \\
\text { reflective evaluation method } \\
\text { in other fields of expertise in } \\
\text { measuring character formation } \\
\text { of students. }\end{array}$ & $\begin{array}{l}\text { Threat: the influence } \\
\text { of trends and relations } \\
\text { between friends that cannot } \\
\text { be predicted to form }\end{array}$ \\
$\begin{array}{l}\text { 1. Each field of expertise has } \\
\text { its own character value. }\end{array}$ & $\begin{array}{l}\text { 1. The need to be accepted } \\
\text { in relation environment. }\end{array}$ \\
$\begin{array}{l}\text { 2. Character values contained } \\
\text { in the field of expertise can } \\
\text { be used as the development } \\
\text { of instruments to measure } \\
\text { character. }\end{array}$ & $\begin{array}{l}\text { 2. The need for self-existence } \\
\text { by following the trend. }\end{array}$ \\
\hline
\end{tabular}

The findings in the study were based on the reflection that the students had performed. In general, through the study the students shared the customers' life values that they had acquired from the Customer Education Course. Then, the data analysis was based on the percentage of the life values application in the course. The application of the life values in the course might be represented from 
the four alternatives in the questionnaire. The four alternative themselves are as follows: a) performing daily activities by applying the life values; $b$ ) recognizing the life values and often applying the life values in the daily life; c) recognizing the life values, but rarely applying them in the daily life; and (d) recognizing the life value, but never applying them in the daily life. The classification for the customers' life values application would be presented in Table 2.

Table 2. Classification on the score of life values application

\begin{tabular}{c|c:c}
\hline Class & Scores & Category \\
\hline 1 & $>199-244$ & Very good \\
\hdashline 2 & $>153-199$ & Good \\
\hdashline 3 & $>107-153$ & Moderate \\
\hdashline 4 & $61-107$ & Poor \\
\hline
\end{tabular}

\section{RESULTS}

\subsection{The implementation of life values}

The importance of Customer Education Course could not be denied, as the course delivered a lot of life values that played a significant role in the process of building customers' characters. The importance itself became highly relevant, since hedonism and drug abuse had been common- ly found around the society nowadays. The rise of hedonism and drug abuse in our society itself might be a solid proof of the failure in our education (including the one in the Customer Education Course) for building the students' characters. Such condition indeed heightened the concerns within the Indonesian education and became the challenge of all parties in the education due to the fact that the demand for achieving better competencies and more life values had been higher than ever.

In order to eradicate the negative impacts within the social development, such as the tight competition within the free market system and the rise of malls and shopping centers that might lead to the consumptive behaviors and also drug abuse, the teaching and learning process in the Customer Education should be directed toward developing the aspects that might be necessary for building the noble characters. For ensuring the effective implementation of these values, there should be a synergic cooperation among all stakeholders in the education (family, school/university, and society). Then, one of the ways for educating the society about the importance of internalizing these values might be teaching the Customer Education Course in the higher education institution, specifically in the Fashion Design and Hospitality Department. The teaching of the course was indeed very important, because the course con-

Table 3. Mind map of students' perception on the importance of Customer Education based on fundamental principles

\begin{tabular}{|c|c|c|c|c|}
\hline No. & Basic competencies & Life values & Fundamental principles & $\begin{array}{c}\% \text { of } \\
\text { importance }\end{array}$ \\
\hline 1 & $\begin{array}{l}\text { Defining Customer Education } \\
\text { Course }\end{array}$ & Self-awareness, goal-orientedness & $\begin{array}{l}\text { Critical awareness, activity } \\
\text { involvement, social concern }\end{array}$ & 94.30 \\
\hline 2 & $\begin{array}{l}\text { Describing the principles of } \\
\text { Customer Education Course }\end{array}$ & $\begin{array}{l}\text { Thriftiness, meticulousness, } \\
\text { responsibility, awareness, social care }\end{array}$ & $\begin{array}{l}\text { Critical awareness, activity } \\
\text { involvement, social concern }\end{array}$ & 97.33 \\
\hline 3 & $\begin{array}{l}\text { Describing the benefits of } \\
\text { taking Customer Education } \\
\text { Course }\end{array}$ & $\begin{array}{l}\text { Meticulousness, self-awareness, } \\
\text { demand toward information, thriftiness, } \\
\text { self-awareness, productiveness, } \\
\text { criticality }\end{array}$ & $\begin{array}{l}\text { Critical awareness, activity } \\
\text { involvement }\end{array}$ & 94.38 \\
\hline 4 & Recognizing customer rights & $\begin{array}{l}\text { Meticulousness, goal-orientedness, } \\
\text { ownership, criticality, demand toward } \\
\text { information, fairness }\end{array}$ & $\begin{array}{l}\text { Critical awareness, activity } \\
\text { involvement, social concern }\end{array}$ & 96.00 \\
\hline 5 & $\begin{array}{l}\text { Understanding the obligation } \\
\text { to read product label }\end{array}$ & $\begin{array}{l}\text { Meticulousness, responsibility, } \\
\text { self-awareness, responsibility, self- } \\
\text { awareness, appreciation of money } \\
\text { value, responsibility, self-awareness, } \\
\text { fairness, self-awareness, criticality, } \\
\text { fairness, responsibility, social } \\
\text { tolerance, social care responsibility, } \\
\text { environmental awareness } \\
\text { responsibility, care }\end{array}$ & $\begin{array}{l}\text { Critical awareness, activity } \\
\text { involvement, social concern, } \\
\text { environmental concern, and } \\
\text { solidarity }\end{array}$ & 95.20 \\
\hline 6 & $\begin{array}{l}\text { Understanding and performing } \\
\text { customer protection }\end{array}$ & Sensitivity, social tolerance, care & Social concern, solidarity & 91.00 \\
\hline
\end{tabular}


Table 3 (cont.). Mind map of students' perception on the importance of Customer Education based on fundamental principles

\begin{tabular}{|c|c|c|c|c|}
\hline No. & Basic competencies & Life values & Fundamental principles & $\begin{array}{c}\% \text { of } \\
\text { importance }\end{array}$ \\
\hline 7 & $\begin{array}{l}\text { Initiating individual consumer } \\
\text { protection movement }\end{array}$ & $\begin{array}{l}\text { Responsibility, self-awareness, social } \\
\text { tolerance }\end{array}$ & $\begin{array}{l}\text { Critical awareness, activity } \\
\text { involvement, social concern }\end{array}$ & 84.50 \\
\hline 8 & $\begin{array}{l}\text { Initiating communal customer } \\
\text { protection movement for the } \\
\text { sake of public welfare }\end{array}$ & Social tolerance, care & Social concern, solidarity & 84.50 \\
\hline 9 & $\begin{array}{l}\text { Identifying customer problems } \\
\text { in sales and purchase } \\
\text { agreement along with the } \\
\text { solutions to the problems }\end{array}$ & Meticulousness, self-awareness, care & $\begin{array}{l}\text { Critical awareness, activity } \\
\text { involvement, social concern }\end{array}$ & 94.30 \\
\hline 10 & $\begin{array}{l}\text { Identifying customer problems } \\
\text { in compensation claim along } \\
\text { with the solutions to the } \\
\text { problems }\end{array}$ & Criticality, fairness, care & $\begin{array}{l}\text { Critical awareness, social concern, } \\
\text { and solidarity }\end{array}$ & 92.70 \\
\hline 11 & $\begin{array}{l}\text { Identifying customer problems } \\
\text { in advertisement claim along } \\
\text { with the solutions to the } \\
\text { problems }\end{array}$ & $\begin{array}{l}\text { Meticulousness, criticality, demand } \\
\text { toward information }\end{array}$ & $\begin{array}{l}\text { Critical awareness, activity } \\
\text { involvement }\end{array}$ & 92.70 \\
\hline 12 & $\begin{array}{l}\text { Identifying customer problems } \\
\text { in product quality in relation to } \\
\text { the packaging along with the } \\
\text { solutions to the problems }\end{array}$ & $\begin{array}{l}\text { Meticulousness, criticality, demand } \\
\text { toward information }\end{array}$ & $\begin{array}{l}\text { Critical awareness, activity } \\
\text { involvement }\end{array}$ & 96.70 \\
\hline 13 & $\begin{array}{l}\text { Identifying customer problems } \\
\text { in product quality in relation } \\
\text { to the label along with the } \\
\text { solutions to the problems }\end{array}$ & $\begin{array}{l}\text { Meticulousness, sensitivity, demand } \\
\text { toward information }\end{array}$ & Activity involvement, solidarity & 95.00 \\
\hline 14 & $\begin{array}{l}\text { Identifying customer problems } \\
\text { in product quality in relation } \\
\text { to the suggested proportion/ } \\
\text { serving size along with the } \\
\text { solutions to the problems }\end{array}$ & $\begin{array}{l}\text { Meticulousness, sensitivity, demand } \\
\text { toward information }\end{array}$ & Activity involvement, solidarity & 92.70 \\
\hline 15 & $\begin{array}{l}\text { Identifying customer problems } \\
\text { in product quality in relation } \\
\text { to product standardization } \\
\text { along with the solutions to the } \\
\text { problems }\end{array}$ & $\begin{array}{l}\text { Meticulousness, sensitivity, demand } \\
\text { toward information }\end{array}$ & Activity involvement, solidarity & 91.90 \\
\hline 16 & $\begin{array}{l}\text { Understanding how to file a } \\
\text { complaint }\end{array}$ & Fairness, demand toward information & $\begin{array}{l}\text { Activity involvement, social } \\
\text { concern }\end{array}$ & 91.90 \\
\hline 17 & $\begin{array}{l}\text { Managing personal finance } \\
\text { wisely }\end{array}$ & $\begin{array}{l}\text { Thriftiness, wisdom, appreciation } \\
\text { toward money value }\end{array}$ & $\begin{array}{l}\text { Critical awareness, activity } \\
\text { involvement }\end{array}$ & 94.30 \\
\hline 18 & $\begin{array}{l}\text { Recognizing customer } \\
\text { behavior theory (seeking } \\
\text { information, assessing, } \\
\text { comparing, buying, having } \\
\text { post-purchase evaluation) in } \\
\text { wise buying decision making }\end{array}$ & $\begin{array}{l}\text { Meticulousness, wisdom, self- } \\
\text { awareness, demand toward } \\
\text { information }\end{array}$ & $\begin{array}{l}\text { Critical awareness, activity } \\
\text { involvement }\end{array}$ & 97.60 \\
\hline 19 & $\begin{array}{l}\text { Identifying wise food } \\
\text { consumption }\end{array}$ & $\begin{array}{l}\text { Thriftiness, meticulousness, demand } \\
\text { toward information }\end{array}$ & $\begin{array}{l}\text { Critical awareness, activity } \\
\text { involvement, }\end{array}$ & 96.70 \\
\hline 20 & $\begin{array}{l}\text { Identifying wise clothing } \\
\text { consumption }\end{array}$ & $\begin{array}{l}\text { Meticulousness, self-awareness, } \\
\text { demand toward information }\end{array}$ & $\begin{array}{l}\text { Critical awareness, activity } \\
\text { involvement }\end{array}$ & 97.60 \\
\hline 21 & $\begin{array}{l}\text { Identifying wise beauty } \\
\text { product consumption }\end{array}$ & $\begin{array}{l}\text { Meticulousness, self-awareness, } \\
\text { demand toward information }\end{array}$ & $\begin{array}{l}\text { Critical awareness; activity } \\
\text { involvement; }\end{array}$ & 89.40 \\
\hline 22 & $\begin{array}{l}\text { Identifying wise household } \\
\text { furniture and appliances } \\
\text { consumption }\end{array}$ & $\begin{array}{l}\text { Meticulousness, self-awareness, } \\
\text { goal-orientedness, demand toward } \\
\text { information }\end{array}$ & $\begin{array}{l}\text { Critical awareness, activity } \\
\text { involvement }\end{array}$ & 88.60 \\
\hline 23 & $\begin{array}{l}\text { Identifying wise medicine } \\
\text { consumption }\end{array}$ & $\begin{array}{l}\text { Meticulousness, goal-orientedness, } \\
\text { demand toward information }\end{array}$ & $\begin{array}{l}\text { critical awareness, activity } \\
\text { involvement }\end{array}$ & 94.30 \\
\hline 24 & $\begin{array}{l}\text { Performing good clothing- } \\
\text { consuming behavior }\end{array}$ & $\begin{array}{l}\text { Meticulousness, self-awareness, } \\
\text { sensitivity }\end{array}$ & $\begin{array}{l}\text { Critical awareness, activity } \\
\text { involvement, social concern, } \\
\text { solidarity }\end{array}$ & 96.70 \\
\hline 25 & $\begin{array}{l}\text { Performing good linen- } \\
\text { consuming behavior }\end{array}$ & $\begin{array}{l}\text { Meticulousness, self-awareness, } \\
\text { sensitivity }\end{array}$ & $\begin{array}{l}\text { critical awareness, activity } \\
\text { involvement, social concern, } \\
\text { solidarity }\end{array}$ & 89.40 \\
\hline 26 & $\begin{array}{l}\text { Performing good accessories- } \\
\text { consuming behavior }\end{array}$ & $\begin{array}{l}\text { Meticulousness, self-awareness, } \\
\text { goal-orientedness }\end{array}$ & $\begin{array}{l}\text { Critical awareness, activity } \\
\text { involvement }\end{array}$ & 87.80 \\
\hline 27 & $\begin{array}{l}\text { Performing good cosmetic- } \\
\text { consuming behavior }\end{array}$ & $\begin{array}{l}\text { Meticulousness, self-awareness, } \\
\text { goal-orientedness }\end{array}$ & $\begin{array}{l}\text { Critical awareness, activity } \\
\text { involvement }\end{array}$ & 90.20 \\
\hline 28 & $\begin{array}{l}\text { Performing good medicine- } \\
\text { consuming behavior }\end{array}$ & $\begin{array}{l}\text { Meticulousness, self-awareness, } \\
\text { environmental awareness }\end{array}$ & $\begin{array}{l}\text { Critical awareness, activity } \\
\text { involvement, environmental } \\
\text { concern }\end{array}$ & 93.40 \\
\hline 29 & $\begin{array}{l}\text { Understanding Customer } \\
\text { Education and its activities }\end{array}$ & $\begin{array}{l}\text { Goal-orientedness, demand toward } \\
\text { information }\end{array}$ & $\begin{array}{l}\text { Critical awareness, activity } \\
\text { involvement }\end{array}$ & 95.10 \\
\hline \multicolumn{4}{|c|}{ Mean } & 95.90 \\
\hline
\end{tabular}


tained many life values that had been essential for building the characters of a wise customer. Then, in relation to the study, the general overview on the students' reflective assessment with regards to the importance of learning the Customer Education Course.

The results of the students' reflection implied that the basic competences within the Customer Education Course have been necessary in relation to their role as a customer. The necessity of mastering these basic competencies through the Customer Education Course has been clearly stated by the mean percentage, namely $95.90 \%$.

Based on the results of the students' reflection as well, in relation to moral, the values within the Customer Education Course consisted of the positive ethical values and the negative ethical values. These values are closely related to the responsibility within the society. Furthermore, the students believed that these moral values had been able to help shaping their characters into those of a wise customer, since characters would help them to shape their behaviors and their behaviors would represent their perspective. In turn, the behaviors that represented their actions would reflect their true attitudes. In general, there were 16 moral values from the Customer Education Course that had been found from the results of the students' reflection.

When the results of the students' reflective analysis had been performed thoroughly, it was found that the Customer Education Course had contained adequate moral values for being a wise customer. Thus, the 16 moral values that had been found would certainly be able to shape the characters of a wise customer by the time the students had internalized these values in depth. It was important for the students to develop these life values within their daily life, since these life values might help them to achieve better understanding on the importance of the meaning of the values and to be more familiar with these values in order that they would be able to apply these values whenever they became the customers. In addition, the students also agreed that these life values might help developing an individual's characters in being intelligent in relation to the cognitive, affective, and psychomotor aspects.

\subsection{The effectiveness of life values implementation}

The data in the study showed that the implementation of the life values for the wise customers in building the students' characters had fallen into the "Good" category. The indication was the mean value 174.97 , which had been in the range of ideal scores with the minimum score 61.00 and the maximum score 244.00 . In relation to the data, the findings in the study showed that the students had believed, internalized, and even practiced the life values in their daily life as part of reflection on their character-building efforts. From 123 students who had been involved, 11 students (9.00\%) fell into the "Very Good" category, 106 students $(86.00 \%)$ fell into the "Good" category, and 6 students (5.00\%) fell into the "Moderate" category; all students had been able to practice the life values that they had attained from the Customer Education Course. In other words, it might be concluded that the life values that had been internalized by the students might be well practiced in the students' daily life.

The pursuance of character-building efforts through the implementation of the life values that had been attained from the Customer Education Course was properly conducted. The statement was supported by the finding that 13 out of 16 life values had been well internalized by the students in their character-building efforts. There were only 3 values (care, fairness, and environmental awareness) whose score had been lower than $70.00 \%$. Furthermore, 87 students $(70.73 \%)$ were classified into the group of "Frequently Practiced and Habituated" students, while 36 students (29.27\%) were classified into the group of "Never and Rarely Practiced" students with regards to the implementation of the life values. These findings confirmed once again that the life values that had been attained in the Customer Education had been implicitly well implemented by the students, although without a hundred percent success. As a result, it might be concluded that the life values in the Customer Education Course might be implemented for building the students' characters.

After having observed the aspects of the life values as part of character-building dimension, the frequency on the practice of the life values was presented in Table 4. 
Table 4. Practices of life values in Consumer Education curriculum/materials

\begin{tabular}{|c|c|c|c|}
\hline \multirow[b]{2}{*}{ No: } & \multirow{2}{*}{$\begin{array}{l}\text { Consumer } \\
\text { life } \\
\text { values }\end{array}$} & \multicolumn{2}{|c|}{ Life values in practice } \\
\hline & & $\begin{array}{c}\text { Frequently } \\
\text { practiced and } \\
\text { habituated, \% }\end{array}$ & $\begin{array}{c}\text { Never and rarely } \\
\text { practiced and } \\
\text { habituated, \% }\end{array}$ \\
\hline 1 & Self-awareness & 74 & 28 \\
\hline 2 & Responsibility & 91 & 9 \\
\hline 3 & Thriftiness & 77 & 23 \\
\hline 4 & Wise & 78 & 22 \\
\hline 5 & $\begin{array}{l}\text { Goal- } \\
\text { orientedness }\end{array}$ & 74 & 26 \\
\hline 6 & Meticulousness & 84 & 16 \\
\hline 7 & $\begin{array}{l}\text { Demand } \\
\text { toward } \\
\text { information }\end{array}$ & 79 & 21 \\
\hline 8 & $\begin{array}{l}\text { Social } \\
\text { tolerance }\end{array}$ & 97 & 3 \\
\hline 9 & Sensitivity & 77 & 23 \\
\hline 10 & Criticality & 75 & 25 \\
\hline 11 & Care & 47 & 53 \\
\hline 12 & Fairness & 53 & 47 \\
\hline 13 & Ordinariness & 79 & 21 \\
\hline 14 & $\begin{array}{l}\text { Environmental } \\
\text { care }\end{array}$ & 52 & 48 \\
\hline 15 & Productiveness & 74 & 26 \\
\hline 16 & $\begin{array}{l}\text { Financial } \\
\text { Management }\end{array}$ & 75 & 25 \\
\hline & Average & 74 & 26 \\
\hline
\end{tabular}

From the above, it was clearly shown that the mean score for the internalization of the life values in the Customer Education Course had been equal to $74 \%$. Such percentage suggested that the life values in the Customer Education Course had been effectively implemented by the students as part of their character-building dimension. In further implication, such percentage also suggested that the students had believed on the capacity of these life values in helping them to shape the characters of being a wise customer in the context of their daily life. Therefore, it might be concluded that the teaching of these values in the Customer Education Course might be effective for building the students' characters. Despite the belief, due to the fact that the internalization of these life values had only been equal to $74 \%$, it might be concluded as well that the students had not been well aware in implementing these life values within the context of their daily life.

\section{DISCUSSION}

\subsection{The implementation of life values}

Teaching and maintaining moral values into children/individuals are part of the main duties that all parties should perform, since these moral values are important building blocks and foundation for the embodiment of civilized and prosperous society (Megawangi, 2004). The statement is in line with the results of the students' evaluation on the life values that they have mastered from the Customer Education Course. The evaluation itself leads to the fact that there were 16 moral values that the students have internalized from attending the course. According to the students' opinions, the 16 moral values support them in being a wise customer, especially when they are able to internalize them into the parts of their attitudes and behaviors in the daily life, since the character and the personality of an individual are shaped by the values that the individuals master, internalize, and consistently implement in the course of the daily life. Not to mention, the values that an individual has might be reflected in his or her behaviors.

Within the study, the students have perceived the main life values that might assist them in dealing with the highly influential information. These life values should be understood and be appreciated and should also be internalized and be practiced in the context of their daily life, since these life values might be a driving force or a guiding principle in their life. Therefore, the students should seriously understand the life values that the schools and the society have held and the values that they have learned might be a significant advantage the character development within the individual or the society.

Then, the more important thing is that the values in the Customer Education Course that the students have internalized might bring about certain contributions to the students' character development so that the students might be wise customers. Perry and Morris (2005) described that individuals with better rate of customer education are more inclined to save their income and to set certain budget as part of their 
future financial planning. In other words, an individual with better rate of customer education will take more effective actions not only in the simple financial calculations in relation to the budget, but also in his or her consideration on the purchase of more sophisticated product (Lantara \& Kartini, 2014). The statement is in line with the opinion by Lusardi and Mitchell (2011) who stated that there is a positive association between financial literacy and personal financial management. Thereby, Customer Education should provide a positive imprint on an individual's customer behaviors in order that the individual will be wise, smart, and financially literate in relation to his or her purchase decision. In relation to the objective, the life values in the Customer Education Course will certainly be useful within the context of an individual's daily life.

The students also state that the life values in the Customer Education Course have been so important that every individual should abide to these values, since every individual around the globe should have master the principles of being a wise customer. Their opinion has been $100 \%$ confirmed by the fact that it is very important to learn and to master the life values in the Customer Education Course. Even other studies that have been relevant to the present study also conclude that the education of life values is important to be early performed in both the family and the school environment so that the students will be equipped with the high value awareness; in turn, these values will continuously motivate the children to behave wisely.

Financial courses in the educational programs of many universities might help the students to handle their financial matters better and to improve their financial welfare (Ergün, 2017). Ali et al. (2004) explained that Customer Education programs might help young people with the skills that they have been equipped with in order to make their financial decisions. According to Choudhary and Kamboj (2017), the importance of financial education is globally acknowledged as a key element to the financial welfare of an individual, as well as the financial stability of a country. Several findings from previous researchers' supports that Customer Education should be taught in the curriculum of higher education institutions, since such course might help students to be a wise customer. Thus, the learning process on the mastery of the life values within the Customer Education Course might be habituated by the students in order to attain high value awareness and to perform wise behaviors in accordance to the humanity values.

Furthermore, Ryan and Lickona (1992) urged that it is no coincidence that the moral power of society is involved in actions that bring about destruction. The characters of a society might be observed from the prevailing characters that the young generation of the society displays. In relation to the statement, it is clear that building a moral society becomes the responsibility of all parties.

Children will turn into honorable individuals if they live in a good environment. In order to ensure that, there should be common efforts toward the goal. Therefore, it might be implied that human beings do not automatically turn into wise individuals with good morality as they enter their adulthood. The growth of the children into such honorable individuals is a result of lifelong efforts that have been pursued both by the individuals and the society (Aristotle, 1987). Providing the assurance toward the achievement of the goal is such a great challenge and consequently there should be awareness from all parties who live around the young people to inform that character education, or values education, is highly important to perform. Fraczek (2013) concluded that cooperation between government and university should enable the transfer of knowledge, norms, and verified solutions from one to another. With regards to the situation, the Customer Education should be performed explicitly in a planned procedure through a focused and comprehensive project so that a society with full of honorable individuals might be created. In addition, Chichowicz and Nowak (2017) emphasized that Customer Education should be performed in order to not only limit the possibility of losing awareness, but also to expand the awareness so that students will be capable to make more conscious decisions whenever they have such information. 


\subsection{The effectiveness of life values implementation}

Customer Education takes the very first step in the participation for improving the educational quality under the efforts of developing individuals' characters. Despite the idealistic statement, drug abuse has been rampant nowadays and, at the same time, consumptive behaviors have been penetrating the young generation. In relation to such situation, Customer Education has a significant role in preventing the performance of inappropriate behaviors. Yoshino et al. (2015) stated that the importance of performing Customer Education comes principally from better decisions with regards to financial allocation. Meanwhile, Agarwalla et al. (2012) in their study concluded that the elevation on the financial knowledge among the students with regards to their financial-handling manner might improve the quality of the schooling education itself. The presence of Customer Education in the curriculum therefore might impact not only the students, but also the quality of the higher education quality.

With regards to the urgency of performing Customer Education, the students have various reasons about the idea. Several students state that they have been concerned with the current condition of the young generation since, along with the rapid development of science and technology, the influence of fast-moving information might erode the moral values and the characters that the children should internalize. Then, other students state that many children have not understood the customer values nowadays and consequently they are inclined to be consumptive. Based on these statements, the internalization of life values through Customer Education might guide the customers in teaching the children to be more critical, thrifty, meticulous, thorough, economical, and responsive to social problems, as well as to be caring toward others. Albeedy and Gharleghi (2015) also proposed that students should be educated at one point of their life on how to obtain at a later stage of life and where else to educate them if not in college. By delivering substantial life values in every lecture and every role model within the home, the school, and the society, it might be expected that students will understand and implement the values that they have internalized from the three environments. These findings are supported by the findings from a study by Carr (1993), which concluded that the values of an individual will be influenced, both consciously and unconsciously, by the examples that have been internalized through his or her teacher within the students' teaching-learning process, behaviors, and relationships.

The character-building efforts of the students in the study might be considered good enough, since the study seeks to internalize the life values that might have been integrated into the curriculum or the materials of the Customer Education Course. As a result, the provision of role model and the internalization of life values for developing the students' characters should be maintained and even should be improved. The provision and the internalization even have higher level of importance, since not all of these values are frequently implemented by the students. For example, there are 3 life values that have earned low scores in the study. Therefore, the continuous provision and internalization on the life values will assist the students in shaping themselves into wise customers within the context of their daily life.

The internalization of life values among the students has not been given significant attention under the students' character-building efforts. The statement has been confirmed by students' habit in implementing the life values into the context of their daily life. With regards to the situation, $76 \%$ instead of $80 \%$ of the students indicated they have been increasingly aware to the implementation of the life values that they have mastered. Based on the finding, it might be concluded that the character-building efforts should not only be determined by the conduct of character education through the delivery of positive messages, but also by the teaching of life values through reflective and meaningful learning process. The combination of the two methods through a harmonious manner will provide competitive advantage for the efforts of nurturing positive characters. In other words, the students' characters will be well developed if the learning process always involves the stu- 
dents into reflective activities. The statement implies that every learning materials should always be delivered through reflective and meaningful method and the message of each learning material should be interpreted in depth with regards to the positive values so that the students might help themselves to develop the characters of being wise customers.

Last but not least, the results of the study also uncover the reasons why the students do not implement the values that they have internalized from the Customer Education Course. According to these students, these life values are complicated and thus trying to implement these values is a waste of time; not to mention, these students have also been burdened by so many assignments. Based on their reasons, it might be concluded that there should be continuous efforts toward helping the students to internalize the life values through various learning methods. Within the learning process, the students should be invited to identify numerous problems within the society and the problems themselves might be related to the loss that customers might experience. Through the discussion over the cause of loss and profit, it is expected that the students might find the appropriate solutions and the customers' rights, as well as the obligations that they should perform.

\section{CONCLUSION}

The findings in the study show that on average $95.90 \%$ students regard the curriculum or the learning materials of Customer Education Course as an important and necessary aspect in their life. Then, the students also consider that there might be 16 life values that serve as the part of the character-building dimension. In terms of life values implementation, the mean score that the students have attained is equal to 174.97 and such mean score belongs to the "Ideal" category with the maximum score 244.00 and the minimum score 61.00. Furthermore, with regards to life values implementation 11 students (9.00\%) fall into "Very Good" category, 106 students (86.00\%) fall into "Good" category, and 6 students $(5.00 \%)$ fall into "Fair" category.

The learning materials in the Customer Education Course, which consists of 16 life values, have not been able to effectively develop the characters of a wise customers. $76 \%$ of the students only earned "B" grade (71-75) within the course. The result is still below the standard, since the requirement to pass the course is that at least there should be $80 \%$ of the total students who attain "B" Grade. Therefore, it might be concluded that the use of life values within the Customer Education Course have not been effective for building the characters of a wise customer.

In order to improve the quality of the character-building efforts through the teaching of the life values in relation to the customer life, several efforts might be suggested. First, there should be improvement on the teachers' or the lecturers' self-awareness so that the teachers or the lecturers will always be willing to continuously internalize the life values through a structured manner without having to be instructed by the leadership of the schools or the university. Second, the Customer Education should be integrated into the schools' or the universities' curriculum so that the Customer Education does not have to be performed through formal courses. In addition, the Customer Education might be performed by providing deliberate interventions such as reflective activities and specially designed tasks so that the students will be assisted in internalizing the life values outside their class. Third, there should be increasing opportunities for the teachers' or the lecturers' creative development, especially in designing the learning materials, the learning strategies, and the learning scenarios of the value education. By doing so, the value education might be well integrated into the course materials so that an effective and meaningful learning process might be created. Fourth, or the last one, there should be a design for the learning process of the value education by relying on the collaborative learning strategies in order to assist the students in effectively internalizing the life values. 


\section{REFERENCES}

1. Agarwalla, S. K., Barua, S., Jacob, J., \& Varma, J. R. (2012). a survey of financial literacy among students, young employees and the retired in India. Citi Foundation: Indian Institute of Management Ahmedabad.

2. Albeerdy, M. I., \& Gharleghi, B. (2015). Determinants of the financial literacy among college students in Malaysia. International Journal of Business Administration, 6(3), 15-24. Retrieved from http:// www.sciedu.ca/journal/index.php/ ijba/article/viewFile/6874/4114

3. Ali, P., Anderson, M., McRae, C., \& Ramsay, I. (2014). The financial literacy of young Australians: An empirical study and implications for consumer protection and ASIC's national financial literacy strategy. The Financial Literacy of Young Australians.

4. Alsubaie, M. A. (2016). Curriculum Development: Teacher Involvement in Curriculum Development. Journal of Education and Practice, 7(9). Retrieved from https://files.eric.ed.gov/fulltext/ EJ1095725.pdf

5. Amble, N. (2012). Reflection in action with care workers in emotion work. Action Research, 10(3), 260-275.

6. Anonym. Department for Democracy and Social Development Education Division (2003). Education for All: a Human Right and Basic Need. Gothenburg: Elanders Novum AB. Retrieved from https://www.sida. se/contentassets/dd486cf7adc7451 6a5c974c2d260c8b5/13138.pdf

7. Aristotle (1987). The nichomachean ethics (J. E. Weldon, Trans). Albuquerque, NM: American Classical College Press.

8. Bannister, R. (1996). Consumer education in the United States: A historical perspective. Retrieved from http://emich.edu/coe/monday/mr 231.html

9. Bloom, B. S. (2001). Taxonomy of educational objective. New York: David Mc. Kay Company Inc.
10. Brooks, D., \& Goble, F. G. (1997) The case for character education: The role of the school in teaching values and virtue. California: Studio 4.

11. Calendra, M., \& Tamarrow (2015). The Assessment of Learning from Competence to New Evaluation. Procedia-Social and Behavioral Science, 174, 3885-3892.

12. Carr, S. (1993). Cambridge series in environment and behavior. England: Cambridge University Press.

13. Chaddock-Heyman, L., Erickson, K. I., Voss, M. W., Powers, J. P., Knecht, A. M., Pontifex, M. B. et al. (2014). White matter microstructure is associated with cognitive control in children. Biological Psychology, 94, 109-115.

14. Cheng, Y. C. (2001). Paradigm Shifts in Quality Improvement in Education: Three Waves for the Future. The International Forum on Quality Education for the Twentyfirst Century Co-organized by UNESCO-PROAP, National Commission for UNESCO of Ministry of Education, and National Institute of Educational Research, China Beijing, China 12-15 June 2001. Retreived from https:// home.ied.edu.hk/ yccheng/doc/ speeches/12-15jun01.pdf

15. Chichowicz, E., \& Nowak, A. K. (2017). Review of research on financial literacy and education of poles. Journal of Insurance, Financial Markets and Consumer Protection, 26(4), 3-18.

16. Choudhary, K., \& Kamboj, S. (2017). A study of financial literacy and its determinants: evidance from India. Asian Journal of Accounting Perspective, 10(1), 52-72.

17. Elder, B. C. (2015). Right to Inclusive Education for Students with Disabilities in Kenya. Journal of International Special Needs Education, 18(1), 18-28. Retrieved from https://www.globaldisabilityrightsnow.org/sites/default/ files/related-files/380/Kenya $\% 20$ Inclusive_Education_in_KenyaBrent\%20Elder.pdf
18. Eng, C-J., \& Pai, H-C. (2014). Determinants of nursing competence of nursing students in Taiwan:The role of self-reflection and insight. Nurse Education Today. http://dx.doi.org/10.1016/j. nedt.2014.11.021

19. Ergün, K. (2017). Financial literacy among university student: a study in eight European countries. International Journal of Consumer Studies. Wiley. https://doi. org/10.1111/ijcs. 12408

20. Fraczek, B. (2013). National strategies for financial education. The concept and first experiences in the world. Department of Banking and Financial Markets, University of Economics in Katowice.

21. Fry, H., Ketteridge, S., \& Marshall, S. (2009). A Handbook for Teaching and Learning in Higher Education Enhancing Academic Practice (3rd ed.). United Kingdom: Taylor \& Francis. Retrieved from http:// biblioteca.ucv.cl/site/colecciones/ manuales_u/A\%20Handbook\%20 for $\% 20$ Teaching $\% 20$ and $\% 20$ Learning\%20in\%20Higher\%20 Education\%20Enhancing\%20academic\%20and\%20Practice.pdf

22. Heath, H. (1998). Reflection and patterns of knowing in nursing. Journal of Advanced Nursing, 27(5), 1054-1059.

23. Lantara, I. W. N., \& Kartini, N. K. R. (2015). Financial literacy among university students: empirical evidence from Indonesia. Journal of Indonesian Economy and Business, 30(3), 247-256.

24. Lile, R., \& Bran, C. (2014). The assessment learning outcomes. Procedia-Social and Behavioral Science, 163, 125-131.

25. Lusardi, A., \& Mitchell, O. S. (2011). Financial Literacy and Planning: Implications for Retirement Wellbeing. England: Oxford University Press.

26. Mardapi, D. (2004). Preparation of learning outcomes tests. Yogyakarta. Postgraduate program, Yogyakarta State University. 
27. Mathew, O. O., Sola, A. F., Oladiran, B. H., \& Amos, A. A. (2013). Efficiency of newman allocation procedure over other allocation procedures in stratified random sampling. American Journal of Theoretical and Applied Statistics, 2(5), 122-127.

28. McGregor, S. L. T. (2005). Sustainable consumer empowerment through critical consumer education: a typology of consumer education approaches. International Journal of Consumer Studies, 29(5), 437-447. https://doi.org/10.1111 /j.1470-6431.2005.00467

29. Megawangi, R. (2004). Pendidikan karakter solusi yang tepat untuk membangun bangsa. Jakarta: Star Energy (Kakap) Ltd.

30. Ololube1, N. P., Aiya, F., Uriah, O. A., Ololube, D. O. (2016). Strategic Planning: A Universal Remedy for the Successful Management of 21st Century University Education (UE). Man- agement, 6(3), 76-88. Retrieved from: http://article.sapub. org/10.5923.j.mm.20160603.03 html

31. Perry, V. G., \& Morris, M. D. (2005). Who is in control? The role of self perception, knowledge and income in explaining consumer financial behavior. Journal of Consumer Affairs, 39, 299-313.

32. Pollard, A. (2002). Reflective teaching: Effective and evidence-informed professional practice. New York: Continuum.

33. Putrohari (2009). Measurement of competence achievement. Retrieved from http:// putrohadi.tripod. com/mengukur_pencapaian.htm

34. Ryan, K., \& Lickona, T. (1992). Character Development in Schools and Beyond. Washington: The Council for Research in Values and Philosophy.

35. Stanszus, L. et al. (2017). Education for sustainable consumption through mindfulness training: Development of a consumtionspecific intervention. Journal of Teacher Education for Sustainability, 19(1), 5-21.

36. Tantri (1995). Gerakan organisasi konsumen. Jakarta: Yayasan Lembaga Konsumen Indonesia.

37. Toros, K., \& Medar, M. (2015) Social work students' thoughts on self-reflection: A qualitative study based on reflective journaling. International Journal of Humanities and Social Science, 5(3), 89-96.

38. Trespeces, F. A. (1993). The CIPP Model. Qoezon City: Innotech.

39. Yamin, M. (2009). Competency Based Learning Strategy. Jakarta: Gaung Persada Press.

40. Yoshino, N., Morgan, P., \& Wignaraja, G. (2015). Financial education in asia: Assessment and recomendations (ADBI Working Paper 534). Tokyo: Asian Bank Institute. 